\title{
Study on Income Generation Activities of Self Help Group and Motivational Level of Women Self Help Group Members in Nagaland, India
}

\author{
Nchumthung Murry ${ }^{*}$, R. Nakhro and Sanjoy Das \\ Department of Agricultural Economics, Nagaland University, SASRD, Medziphema-797 106 \\ Nagaland India, India \\ *Corresponding author
}

\section{A B S T R A C T}

\section{Keywords}

Income generation activities,

Motivation, Women, Self help group, Nagaland

\section{Article Info}

Accepted:

22 July 2020

Available Online:

10 August 2020
Inclusion of women in any governmental and institutional developmental agenda has gaining overall significance with an aim to empower women in various spheres of social, economic, political life. Self help group approach is instrumental in reaching out with the group of women together to work as group in achieving common goal. The present study was conducted in four districts of Nagaland viz., Wokha, Mon, Phek and Dimapur. A total of 120 SHG and 360 respondents by adopting multistage random sampling technique. The study revealed that women SHG undertake diversified Income Generation Activities out of which, the dominant enterprise for income generation adopted by the SHG where, crop production, followed by animal husbandry, value addition of food produce which was adopted by 27.50, 17.50 and 15.83 per cent of the sampled SHG. Moreover motivational level gained as a result of women SHG participation revealed that, out of 7 social and economic variables, participation in SHG increase household income obtain the highest total score of 1322 and was ranked first, followed by participation in SHG creates employment opportunities and participation in SHG helps in overcoming household indebtness, was ranked second and third with a total score of 1311 and 1283 respectively.

\section{Introduction}

Inclusion of women in policy course of action plays an important role as constitutes half of the total population contributing significantly in the total workforce of our country. Emphasis has been given to women for equal representation in various social and political spheres, as have seen through $74^{\text {th }}$ constitution amendment to envisaging greater women participation in municipalities and local governance (Singh, 2013). Unless women are provided with gainful, problem of poverty cannot be solved and will continue in our country, in the face of the implementation of several five year plans and anti-poverty measures and developmental agenda (Taramol, 2014). The concept of self help group acknowledged that financial assistance to the weaker segment of the society who 
remains outside the preview of formal banking and thereby, contributing to the social and economic enrichment, financial sustainability and enhance delivery mechanism for the bank as well (Ramakrishna and Haberberger, 2008).

In the Northeast region of India, the SHGsBank linkage programme started around 1997-98 and since then has gain momentum in the recent past and the number of SHGs has increased considerably. In the recent past, it has been observed that, many government/ NGOs development schemes and social welfare oriented schemes are targeting SHGs in reaching out to the mass, as they are easily accessible with high degree of flexibility in approach.

In this context, the present study was undertaken to identify different types of income generation activities undertaken by SHG and to assess the motivational level gained by tribal women in Nagaland as a result of SHG participation.

\section{Materials and Methods}

The study is a combination of both descriptive and analytical. The present study was conducted in four districts of Nagaland viz., Wokha, Mon, Phek and Dimapur districts of Nagaland. Multistage random sampling method was adopted for selecting the sample of SHG members. Out of 11 districts in Nagaland, 4 districts viz., Wokha, Mon, Phek and Dimapur districts were purposely selected.

All together a total of 120 SHG and 360 respondent were selected for the detailed study. The motivation level of women SHG participants on social and economic variables was analyzed by collecting the opinion of the respondents covering various social and economic issues on five-point rating scale.

\section{Results and Discussion}

Income Generation Activities (IGAs) undertaken by Women Self Help Group (SHG) in Nagaland

Income Generation Activities (IGAs) undertaken by the SHG serves as an engine for the growth and sustainability of SHG in long run, as they earn economic return and generate savings and profits to the group. There are diversified income generation activities undertaken by women self help groups in Nagaland but, in this paper, effort has been made to identify the most predominant enterprise undertaken by each SHG considered in the study. Table 1 shows the Income Generation Activities (IGAs) undertaken by Women Self Help Group (SHG) in Nagaland.

Women SHG undertake diversified Income Generation Activities in Nagaland, Out of which 27.50 per cent of the SHG were engaged in crop production and was found to be most dominant enterprise adopted by the SHG followed by animal husbandry (17. 50 per cent), value addition of food produce (15.83 per cent) which was ranked second and third respectively. Crop production activities and animal husbandry has been the most dominant enterprise as most of the SHG members predominantly belongs lower income group and involve in agricultural activities, moreover, resources for different undertaking different agricultural activities are at their disposal. Perumal, 2005; Uma, and Narasaiah, 2017; Sundaram, 2001, also revealed similar findings in their study. Value addition among SHG in terms of pickle/ jam/Squash making, dried fruit products has been gaining more popularity with the intervention of extension machineries and training. Other income generation activities undertaken by SHG in the study area include waving/ handloom (13.83 per cent), catering 
(12.50 per cent), petty shop (5.83 per cent) and fishery (5.83 per cent) which was ranked fourth, fifth, sixth and seventh respectively. It is observed that, waving/ handloom has been a part and parcel of traditional tribal Naga old age practice and even these days many SHGs are taking up waving/ handloom as a group in commercial way. Catering activity in mostly observed in semi urban and urban are where SHGs involved in catering activities during social event, marriage ceremony etc. Tripathy, 2004; Anantkumar, 2006; Mishra and Hossain, 2001, also made similar study on self help group and concluded on similar line.

Table.1 Income Generation Activities (IGAs) undertaken by Women Self Help Group (SHG) in Nagaland

\begin{tabular}{|l|l|l|l|l|}
\hline SI. No & Income Generating Activities & Frequency & Percentage & Rank \\
\hline $\mathbf{1}$ & Crop production & 33 & 27.50 & I \\
\hline $\mathbf{2}$ & Animal Husbandry & 21 & 17.50 & III \\
\hline $\mathbf{3}$ & Value addition of Food produce including & 19 & 15.83 & II \\
\hline $\mathbf{4}$ & Waving/ Handloom & 16 & 13.33 & VI \\
\hline $\mathbf{5}$ & Catering & 15 & 12.50 & IV \\
\hline $\mathbf{6}$ & Petty Shop & 9 & 7.50 & V \\
\hline $\mathbf{7}$ & Fishery & 7 & 5.83 & VII \\
\hline $\mathbf{8}$ & Total & $\mathbf{1 2 0}$ & $\mathbf{1 0 0 . 0 0}$ & \\
\hline
\end{tabular}

Table.2 Motivational level of Women Self Help Group members towards various Social and Economic factors

\begin{tabular}{|l|l|c|c|c|c|c|c|c|}
\hline $\begin{array}{l}\text { SI. } \\
\text { No }\end{array}$ & Socio and Economic Variable & SDA & DA & UD & A & SA & $\begin{array}{l}\text { Total } \\
\text { score }\end{array}$ & Rank \\
\hline $\mathbf{1}$ & $\begin{array}{l}\text { Participation in SHG increase } \\
\text { household income }\end{array}$ & 7 & 27 & 95 & 179 & 52 & 1322 & I \\
\hline $\mathbf{2}$ & $\begin{array}{l}\text { Participation in SHG creates } \\
\text { employment opportunities }\end{array}$ & 18 & 38 & 85 & 133 & 86 & 1311 & II \\
\hline $\mathbf{3}$ & $\begin{array}{l}\text { Participation in SHG helps in } \\
\text { overcoming household indebtness }\end{array}$ & 17 & 42 & 94 & 135 & 72 & 1283 & III \\
\hline $\mathbf{4}$ & $\begin{array}{l}\text { Participation in SHG enhance social } \\
\text { participation of women }\end{array}$ & 7 & 49 & 101 & 142 & 61 & 1281 & IV \\
\hline $\mathbf{5}$ & $\begin{array}{l}\text { Participation in SHG increase access } \\
\text { public amenities }\end{array}$ & 11 & 51 & 104 & 122 & 72 & 1273 & V \\
\hline $\mathbf{6}$ & $\begin{array}{l}\text { Participation in SHG induce more } \\
\text { political participation }\end{array}$ & 16 & 54 & 88 & 146 & 56 & 1252 & VII \\
\hline $\mathbf{7}$ & $\begin{array}{l}\text { Participation in SHG enhance } \\
\text { decision making ability on important } \\
\text { family matters }\end{array}$ & 22 & 57 & 86 & 131 & 64 & 1238 & VIII \\
\hline
\end{tabular}

SA - Strongly Agree (5), A - Agree (4), UD- Undecided (3), DA- Disagree (2) and SDA Strongly Disagree (1). 
In order to measure the motivational level of women Self Help Group members towards various social and economic issue, 7 variables of social and economic motivational factors were identified viz., participation in SHG helps in overcoming household indebtness, participation in SHG enhance social participation of women, participation in SHG induce more political participation, participation in SHG increase household income, participation in SHG creates employment opportunities, SHG increase access public amenities, and participation in SHG enhance decision making ability on important family matter. Motivational level of women Self Help Group members towards various Social and Economic issue is given in table 2 .

\section{Social and economic motivational level of women self help group participation}

Self Help Group (SHG) participation helps women to gain economic and social independence. Motivational level of Women Self Help Group members towards various Social and Economic factors is shown in table 2.

From table 2, it is evident that out of 7 social and economic variables for determining the motivational level of SHG members, the variable; participation in SHG increase household income obtain the highest score of 1322 and was ranked first, followed by Participation in SHG creates employment opportunities, participation in SHG helps in overcoming household indebtness and Participation in SHG enhance social participation of women, which was ranked second, third and fourth, with a total score of 1311, 1283 and 1281 respectively. Other variables on motivational factor of SHG include, participation in SHG increase access public amenities, participation in SHG induce more political participation and participation in SHG enhance decision making ability on important family matters which was ranked fifth, sixth, seventh and eighth with a total score of 1273, 1252, 1238 respectively. Based on the ranked and total score obtained by the different parameter of social and economic motivational factors, it is evident that motivational level gained in terms of economic factors is more as compared to social factors considered in the study. Kumar, 2009; Singh and Gupta, 2017; Murry and Nakhro, 2019, also done a similar study on self help group contribution on social and economic life and concluded on similar line.

In conclusion, with a growing popularity of Self Help Group movement, many micro finance institutions and funding agencies including banking sector, emphasised on women beneficiaries as women are found to be more reliable and financial viability. SHGs emerged as a valuable instrument for inclusion of socially and financially poorer and feeble women into the mainstream of nation's growth and progress. In the state of Nagaland SHG movement has seen tremendous progress especially among women. From the present study it was concluded many diversified income generation activities are being undertaken by the SHG as an viable economic source of income, crop production, animal husbandry, value addition of food produce, waving/ handloom, catering, petty shop and fishery are the most practiced viable IGAs among tribal women in Nagaland. It was also concluded that, motivational level gained in terms of economic factors is more as compared to social factors considered in the study.

\section{References}

Anantkumar. 2006. Self Help Groups, Women's Health and Empowerment: Global thinking and contextual issues. Jharkhand Journal of Development and 
Management Studies. 4(3): 61-79.

Kumar, R. 2009. A study on the performance of Self Help Groups in Coimbatore District, in micro finance- Performance evaluation and enterprise development, Edited by Lazar. D and Malabika Deo, Published by Allied Publishers, Chennai. 242-45.

Mishra, M and Hossain, M. 2001. Panchayat Raj and Rural Development in Orissa. Indian Journal of Social Development. 1(1): 453.

Murry, N. and Nakhro, R. 2019. Perception on socio economic impact of self help group Participation by tribal women in Nagaland. International Journal of Educational Science and Research. 9(6): $11-16$

Perumal, V.M.S. 2005. SHGs: Empowering Women at the Grassroots. Social Welfare. 52(4): 5-9.

Ramakrishna and Haberberger. 2008. Good practices in SHG book keeping: Three Case Studies -Microfinance in India. SAGE Publications Pvt. Ltd.

Singh, U. B and Gupta, T. 2017. Does SHG bank linkage programme lead to the women empowerment. International Journal of Scientific and Research. 7(7): $121-5$

Singh, Y.,2013. Effect of Self Help Group in economic empowerment of rural women in Himachal Pradesh. Journal of Indian Research. 1(3): 54-61.

Sundaram, I. S. 2001. Self-Help Groups: Challenges and Opportunities. Social Welfare. 48(4): 18.

Taramol., K. G. 2014. Eradication of poverty and women empowerment - A study of Kudumbashree Projects in Ernakulum District of Kerala, India. International Review of Research in Emerging Markets and the Global Economy. 1(4): 236-241.

Tripathy, K.K. 2004. Self Help Groups: A Catalyst of Rural Development. Kurushetra. 52(8): 40-43.

Uma, D. K and Narasaiah, L. 2017. Women empowerment through Self Help Groups: An empirical study in Kurnool district of Andhra Pradesh. International Journal of Applied Research. 3(1): 1015.

\section{How to cite this article:}

Nchumthung Murry, R. Nakhro and Sanjoy Das. 2020. Study on Income Generation Activities of Self Help Group and Motivational level of Women Self Help Group Members in Nagaland, India. Int.J.Curr.Microbiol.App.Sci. 9(08): 2517-2521. doi: https://doi.org/10.20546/ijcmas.2020.908.288 